\title{
A PHÝSIS COMO FUNDAMENTO DO SISTEMA FILOSÓFICO ESTOICO ${ }^{I}$
}

\author{
Andityas Soares de Moura Costa Matos ${ }^{2}$ \\ andityas.matos@fead.br
}

RESUMO $O$ presente artigo pretende demonstrar como a Física foi imprescindivel para o sistema filosófico estoico, o que permitiu a sua utilização na Antiguidade como fundamento de todo o pensamento do Pórtico. Objetivase inferir tal papel preponderante reservado à Física estoica mediante a análise de alguns dos seus principais temas, tais como a Ontologia corporalista que a informa e as noções de lógos, deus e mistura total, concluindo-se o texto com uma breve exposição da teoria das conflagrações.

Palavras-Chave Estoicismo antigo, Ontologia, Metafisica, Causalismo, Conflagrações

ABSTRACT The purpose of this paper is to demonstrate how Physics played a vital role in the development of the Stoic Philosophy System and allowed its use in ancient times as a basic element of the whole Portico's thought. This paper also intends to infer the significance of that role played by Stoic Physics, analyzing some of its main themes - the Ontology of the bodies, used, for instance, as an information source; and the notions of lógos, god

1 Foram utilizadas neste texto, entre outras, as seguintes coleções de fragmentos estoicos e de filósofos antigos, indicadas no artigo pelas siglas em negrito: 1) ARNIM, 1968 [SVF]. É esta a compilação clássica; 2) INWOOD; GERSON (Org.), 1997 [IG]; 3) KIRK; RAVEN; SCHOFIELD. [KRS]; 4) LONG; SEDLEY (Org.), 2006. [LS]. Este volume é tido como a melhor compilação de fragmentos da Filosofia Helenística, superando atualmente a obra de Arnim no que se relaciona aos estoicos; 5) SCHUHL, 2002 [ST]. Reúne o essencial dos escritos do estoicismo greco-romano, todos eles acompanhados de copiosas notas e de esclarecedoras notícias.

2 Doutor em Direito e Justiça pela UFMG. Professor e Coordenador do Curso de Direito da FEAD (Belo Horizonte). Recebido em 11/08/2009 e aprovado em 24/02/2010.

KRITERION, Belo Horizonte, nº 121, Jun./2010, p. 173-193. 
and general mixture. Finally, the article provides a brief explanation of the conflagration theory.

Keywords Ancient Stoicism, Ontology, Metaphysics, Causalism, Conflagrations

A Física integra a parte do discurso filosófico responsável por todas as questões relativas ao mundo natural, conformando um conhecimento que, de acordo com muitos estudiosos, deveria se destinar apenas aos filósofos estoicos mais avançados na compreensão da doutrina, da qual a Física representaria o ápice. ${ }^{3}$ Lima Vaz chega a sustentar que a Física estoica é o tronco que sustenta todo o sistema da Stoá enquanto unidade orgânica e perfeita. ${ }^{4}$ Com efeito, a Física do Pórtico absorve a Ontologia, a Metafísica e a Teologia, além de várias ciências empíricas como a Meteorologia e a Astronomia.

Conforme as premissas fundamentais da Ontologia da Stoá, a realidade se compõe basicamente de entidades corpóreas (somata) - que podem ser causas ou sofrer a ação de outras causas - e de entidades incorpóreas (asómata) que, ao contrário, não existem como as corpóreas, apenas subsistem (huphistasthai) na mente; são quatro: o vazio (kenón), o tempo (chrónos), o espaço (tópos) e o exprimível (lektón). ${ }^{5}$ Os corpos são coisas que se estendem nas três dimensões: comprimento, largura e profundidade. Para os estoicos, tudo que é real é corpóreo, ${ }^{6}$ tese inegociável e que lhes valeu inúmeras críticas por parte das escolas helenísticas rivais. Por seu turno, os incorpóreos não são corpos, mas também não podem ser classificados como não-existentes. São "algo" (tò $t i$ ), ou seja, "quase-seres" que expressam o movimento da natureza. ${ }^{7}$ Os três primeiros incorpóreos representam condições para os processos físicos, enquanto o último liga-se à Filosofia da Linguagem. ${ }^{8}$

Pierre Aubenque entende que a categoria ontológica do "algo", criada pelos estoicos para agasalhar os incorpóreos, acaba por superar a ontologia

4 LIMA VAZ, Henrique Cláudio de. Escritos de filosofia IV: introdução à ética filosófica 1. Loyola: São Paulo, 1999, p. 153.

5 SELLARS, 2006, p. 83.

6 HAHM, 1977, p. 3.

7 GOLDSCHMIDT, 1953.

8 BRUNSCHWIG, 2006, p. 236. 
aristotélica, na qual o "ser" (tò ón) ocupa o status de gênero mais geral. ${ }^{9}$ No estoicismo, ao contrário, existe uma categoria ainda mais ampla do que o "ser" de Aristóteles e que o assimila. Trata-se exatamente do tí, o gênero supremo da ontologia estoica, ${ }^{10}$ acima do ser que é, os estoicos concebiam, portanto, o "algo". "Tanto os corpóreos como os incorpóreos são "algo", embora estes últimos não tenham existência (tò ón) propriamente dita. Devido ao seu caráter paradoxal, a doutrina sofreu modificações por parte de estoicos tardios e heterodoxos como Sêneca. O cordobês via o ser (quod est) como categoria última, ao qual se subsumiriam os corpos e os incorpóreos que, afinal, são quase-seres (quae quasi sunt). ${ }^{12}$

Há notícias doxográficas isoladas e pouco sistemáticas sobre outras categorias ontológicas pensadas pelos estoicos, tais como o "nada", que englobaria "algos" que não são corpóreos e nem incorpóreos, v.g., as entidades ficcionais e os limites geométricos, ${ }^{13}$ e os "não-algos" (oútina), cujo melhor exemplo são os conceitos universais e as formas puras à moda de Platão. ${ }^{14}$ Estas foram combatidas pelos estoicos, que as comparavam a fantasmas do pensamento, dado que não são um "algo" e nem um "algo qualificado", mas antes um "quasi-algo" ou um "quasi-algo qualificado", do mesmo modo que uma imagem de um cavalo nos surge na mente ainda que não haja nenhum cavalo presente. ${ }^{15}$ De qualquer forma, a controvérsia acerca dos estatutos ontológicos estoicos é infindável, como se percebe nos textos de Brunschwig ${ }^{16}$ e de Caston. ${ }^{17}$

Para os estoicos, o conceito (ennoia) fundamental que unifica todo o seu sistema físico - e também lógico e ético - encontra-se na noção de lógos. Se aceitarmos, como quer White, que a Física do Pórtico se sustenta sobre dois "compromissos a priori", quais sejam, as ideias de unidade e de coesão entre o cosmos e a razão divina, ${ }^{18}$ o lógos constitui o elemento capaz de refleti-las e de lhes conferir realidade corpórea. Há uma ordem imanente que rege o universo (kosmos) e mantém o seu equilíbrio, opondo-se ao kaos que pretende dissolver a realidade em indeterminações arbitrárias. Contra os epicuristas, que sustentavam ser o acidente o grande responsável pelo mundo, os estoicos

9 In: CHÂTELET, p.172 et seq.

10 LS, p. 164.

11 BRUNSCHWIG, 2006, p. 244.

12 SÉNECA, 2006, XCV, 13-15, p. 346.

13 LS, p. 163-166.

14 BRUNSCHWIG, p. 247.

15 DIOGĖNE LAËRCE, Vies et opinions des philosophes, VII, 61 (ST, p. 36).

16 BRUNSCHWIG, p. 243-251.

17 CASTON, 1999, p. 215-247.

18 WHITE, 2006, p. 143. 
opuseram um memorável argumento reproduzido por Cícero. Ele sustenta que a beleza e a complexidade do mundo, onde tudo se ajusta perfeitamente, são provas ontológicas da existência de uma inteligência superior que tudo governa e ordena. Não foram átomos rodopiando ao acaso que conformaram este nosso mundo, diz Cícero. Tal lhe parece tão impossível como obter de um só lance todos os versos dos Anais de Ênio lançando ao ar inumeráveis letras que, caindo ao solo, se organizariam de modo eventual, dando lugar ao poema inteiro. Com tal método aleatório não é possível obter sequer uma única linha dos Anais. ${ }^{19} \mathrm{O}$ mesmo raciocínio deve ser aplicado ao universo para compreendermos quão absurda é a ideia de que ele teria surgido acidentalmente e sem o concurso do lógos, determinação demiúrgica racional (logikos) que perpassa a natureza. Na linha de Heráclito, ${ }^{20}$ Zenão identifica o lógos com o fogo-artesão, artífice do mundo. ${ }^{21}$ Trata-se de uma matéria extremamente sutil e capaz de sustentar os paradoxos do pensamento estoico, que exige ao lado de um racionalismo rigoroso, um materialismo estrito. ${ }^{22}$ Às vezes os estoicos chamam o lógos de deus (theos), mas não se trata de um ser divino pessoal como no cristianismo e sim do princípio de racionalidade que se encontra em todas as coisas, em especial no homem, que contém em si os logoi spermatikoi, ${ }^{23}$ ou seja, razões seminais individualizadas capazes de identificar a racionalidade humana com a do próprio Zeus.

Tão alto é o respeito do estoicismo pelo homem que a ordem reinante no interior deste vale como prova cabal da ordem universal, da qual é reflexo, conforme o conhecido silogismo de Marco Aurélio. ${ }^{24}$ Parece-nos que o processo de construção da cosmologia estoica consistiu na exteriorização do que há de mais profundo no homem: a razão. É por isso que os estoicos viam propriedades morais na Física, posição duramente criticada por Pufendorf, para quem não há certo e errado na natureza, que à luz da ciência do seu tempo consistia apenas no movimento e na aplicação de forças físicas às coisas. Assumindo uma posição tipicamente positivista, Pufendorf acredita que o valor não está nos objetos, sendo-lhes imposto pelo entendimento humano. ${ }^{25}$ Ora, a perspectiva da Stoá é diametralmente oposta. Reconhecendo

19 CICÉRON. De la nature des dieux, II, XXXVII, 93 (ST, p. 442).

20 "Todas as coisas são uma igual troca pelo fogo e o fogo por todas as coisas, como as mercadorias o são pelo ouro e o ouro pelas mercadorias" (Fr. 90, 219, KRS, p. 205).

21 DIOGĖNE LAËRCE, Vies et opinions des philosophes, VII, 156 (ST, p. 66).

22 LIMA VAZ, p. 150.

23 ILDEFONSE, p. 26.

24 "Ou um mundo organizado, ou uma papa, um amontoado sem ordem. É possível, acaso, subsista alguma ordem em ti, mas desordem no universo, e isso quando tudo se acha tão combinado, tão fundido, tão solidário?" (MARCO AURÉLIO, 27 [MARCO AURÉLIO, 1973, p. 285]).

25 IRWIN, 2006, p. 390-392. 
o lógos em si mesmo, o filósofo estoico intui a sua existência no cosmos, que passa então a ter qualidades positivas tipicamente humanas: sabedoria, bondade, justiça etc. O Pórtico observa a natureza, em si amorfa e sem sentido, como extensão ou exteriorização da interioridade racional humana. Nessa perspectiva, o estoicismo foi o primeiro grande humanismo da História, incapaz de compreender o mundo separadamente do homem.

Por obra do estoicismo, o objeto (o cosmos) foi posto sob a mesma rubrica ontológica caracterizadora do sujeito (o ser racional), e assim se operou essa espécie de dialética mediante a qual o lógos, interior ao homem, se manifestou em todas as coisas que lhe são exteriores e, por isso mesmo, apenas aparentemente opostas. Não há oposição entre o humano e o mundo porque ambos são tributários do lógos, ambos são expressões ou momentos parciais da razão, que se apresenta em sua inteireza quando o pensamento estoico, exteriorizando o interior, supera os dualismos e os integra em um continuum espaço-temporal que, ao fim e ao cabo, se identifica com todo o Real. Coube aos estoicos reunificar o lógos - antes dilacerado pelos sofistas, que o fraturaram em phýsis e nómos - e recuperar a unidade perdida intuída pelos pré-socráticos.

A Física estoica enxerga o mundo como um ser vivo, ${ }^{26}$ um animal sábio ${ }^{27}$ e totalmente racional ${ }^{28}$ governado pela Providência (pronoia), ${ }^{29}$ dono de uma única alma e de uma única substância, às quais se dirigem todas as percepções, impulsos e causas. ${ }^{30}$ Ademais, como a consciência é um atributo superior à inconsciência, Zenão entende que o mundo, por ser hierarquicamente superior ao homem, apresenta-se como ser vivo consciente. ${ }^{31}$ Este raciocínio provocou a crítica cáustica de Carnéades, que lançando mão de um silogismo semelhante afirmou que o mundo é um ser letrado, eis que o alfabetizado é superior ao analfabeto. $^{32}$

A phýsis se apresenta aos olhos estoicos como algo sagrado, evocando a soma daquilo que é permanente e essencial nos fenômenos naturais. ${ }^{33}$ Há

26 A ideia estoica - também presente no Timeu de Platão - segundo a qual o planeta é um animal vivo de forma esférica foi retomada pela tradição mística do hermetismo neoplatônico, especialmente por Athanasius Kircher. Cf. ROOB, 2006, p. 163.

27 CICÉRON, De la nature des dieux, II, XI, 29 (ST, p. 419).

28 DIOGĖNE LAËRCE, Vies et opinions des philosophes, VII, 139 (ST, p. 60).

29 DIOGĖNE LAËRCE, Vies et opinions des philosophes, VII, 138 (ST, p. 60).

30 MARCO AURÉLIO, IV, 40, p. 286.

31 CICÉRON, De la nature des dieux, II, VIII, 21-22 (ST, p. 416-417) e DIOGÈNE LAËRCE, Vies et opinions des philosophes, VII, 142-143 (ST, p. 61-62).

32 TATAKIS, 1931, p. 89.

33 BLOCH, 1980, p. 15. 
inclusive quem classifique a Física estoica como uma "cosmobiologia". ${ }^{34} \mathrm{O}$ mundo seria uma unidade perfeita, divina, viva, contínua e autocriadora, regida por leis inteligíveis e dirigida por uma espécie de Providência racional ${ }^{35}$ que se encontra em todos os lugares. Assim, o mundo se identifica com deus e deus se identifica com o mundo. ${ }^{36}$ É inegável o influxo de Heráclito na cosmologia estoica: "O deus é dia-noite, Inverno-Verão, guerra-paz, saciedade-fome [todos os contrários, é o que isto significa]". ${ }^{37}$ Também Spinoza amalgama Deus e a natureza - Deus sive Natura, "Deus, ou seja, a Natureza", como se expressa o filósofo -, embora nos pareça exagerado falar de uma influência direta do estoicismo no seu pensamento. ${ }^{38}$

No sistema filosófico da Stoá, a Teologia corresponde à parte da Física responsável pela descrição da coerência geral do universo e de seu desígnio providencial..$^{39} \mathrm{O}$ deus estoico representa o sistema nervoso central do universo, esse enorme animal de forma imaculadamente esférica ${ }^{40}$ que unifica a vida, a dissemina e a partilha por inúmeros corpos particulares e determinados. Tratase de uma visão continuísta, dinâmica, orgânica e racional da realidade física ${ }^{41}$ que, como já notamos, bebe da puríssima fonte de Heráclito: "Dando ouvidos, não a mim, mas ao Logos, é avisado concordar em que todas as coisas são uma." $" 42$

Segundo o Pórtico, há na natureza uma força (tonus) que governa o mundo e o mantém coeso mediante diferentes tensões (hexis) ${ }^{43}$ impostas às coisas: ${ }^{44}$ trata-se do lógos-demiurgo que imprime qualidade e movimento aos corpos, conferindo forma à matéria (hylê) informe. Antes da ação do lógos, a matéria existe apenas como extensão tridimensional sem qualquer outro atributo. ${ }^{45} \mathrm{O}$ tonus pneumático que a informa se apresenta como movimento tensivo (toniké kínesis) mediante o qual o universo "respira", movendo-se simultaneamente

34 HAHM, 1977, p. 136.

35 MARCO AURÉLIO, VII, 9, p. 299-300.

36 SÊNECA, 2005, VIII, 4, p. 39.

37 Fr. 67, 204; KRS, p. 197.

38 Long apresenta várias semelhanças e dessemelhanças verificáveis entre o estoicismo e a filosofia de Spinoza. Cf. LONG, 2006, p. 407-418.

39 ALGRA, 2006, p. 171.

40 Tal porque, segundo Possidônio, a forma esférica é a que melhor se adapta ao movimento. Cf. DIOGÈNE LAËRCE, Vies et opinions des philosophes, VII, 140 (ST, p. 60).

41 ILDEFONSE, 2007, p. 33.

42 Fr. 50, 196; KRS, p. 193.

43 A concepção de tensões como meios de manutenção da unidade do mundo provém originalmente de Heráclito: "Eles não compreendem como é que o que está em desacordo concorda consigo mesmo [à letra: como o que estando separado se reúne consigo mesmo]: há uma conexão de tensões opostas, como no caso do arco e da lira" (Fr. 51, 209; KRS, p. 199).

44 PLUTARCH, Stoic self-contradictions, 1053f-1054b (IG, p. 171).

45 LONG, 2006, p. 410. 
para dentro e para fora. De acordo com Nemésio, o movimento para fora produz a quantidade e a qualidade enquanto o movimento para dentro garante a unidade e a substância do cosmos. ${ }^{46}$ Com base nessa construção, Sambursky viu no estoicismo uma antecipação da noção de campo de força característica da Física dos nossos dias. ${ }^{47}$

O pnê̂ma, termo grego que pode ser traduzido tanto como "espírito" quanto como "vento", é uma substância dinâmica responsável pela coesão dos objetos materiais, pela organização dos seres vivos, pela percepção e pela vontade dos animais e, no homem, pela cognição e pelo entendimento. ${ }^{48} \mathrm{O}$ lógos pneumático se manifesta no fogo como calor, no ar como frialdade e no homem como razão, capacidade própria de seres lógicos, ou seja, detentores da compreensão profunda do lógos, graças à qual, de acordo com Zenão, as representações do mundo são gravadas na alma (psychê) humana; e se transformam a cada passo, complementa Crisipo. ${ }^{49}$ Aparenta-se o homem com os deuses, pois ambos são donos da mesma razão, que nos deuses é perfeita e nos homens perfectível. ${ }^{50}$ Eis um dos pontos em que Spinoza diverge dos estoicos, visto que o pensador judeu entende que o pensamento de Deus difere completamente do nosso, uma vez que somos apenas modos finitos de Deus. ${ }^{51}$

A ideia de deus é descrita como uma pré-noção (prolêpseis) implantada na mente humana. ${ }^{52}$ Caso o homem utilize a sua razão retamente, não poderá deixar de conceber a existência de um princípio criador indestrutível, eterno, providencial e beneficente. ${ }^{53}$ Tal princípio é uno e múltiplo ao mesmo tempo. Para um estoico, não há sentido em separar o deus único dos demais falsos deuses. A polêmica monoteísmo versus politeísmo parece ser absolutamente estéril e vã no tecido teórico do Pórtico. Deus encarna o princípio unitário que percorre todo o universo como uma descarga elétrica constante, capaz de variar as suas tensões e manifestações. Mas a unidade divina não implica unicidade, conclui Duhot. Presente em todas as coisas, deus se manifesta na multiplicidade de suas ações, ${ }^{54}$ o que inclusive serve como comprovação de sua realidade ontológica.

46 NEMESIUS, De natura hominis, 70-71 (IG, p. 283).

47 WHITE, 2006, p. 150.

48 HANKINSON, 2006, p. 331. Cf. também VERBEKE, 1945.

49 Para uma análise da noção estoica de representação e uma breve exposição da consequente teoria da mente, cf. ARTHUR, 1983, p. 69-78.

50 SÉNECA, Cartas a Lucilio, XCII, 27, p. 316.

51 SPINOZA, Ethica, I, prop. 17, corol. 2, esc. In: SPINOZA, 1985.

52 Sobre as pré-noções, cf. JACKSON-McCABE, 2004, p. 323-347.

53 ALGRA, 2006, p. 176.

54 DUHOT, 2006, p. 85. 
Dentre as várias "provas" da existência de deus postas pelos estoicos, ${ }^{55}$ Algra lista três que nos parecem particularmente interessantes e que originaram três argumentos (trópoi) clássicos, quais sejam: a) Consenso omnium, pois a religião e a crença nos deuses são fenômenos universais; b) Ex operibus dei, já que podemos antever deus na estrutura ordenada e racional do universo, cuja mais perfeita expressão reside nos movimentos regulares dos corpos celestes; e c) Ex gradibus entium, dado que o ateísmo acarreta consequências absurdas, tal como a afirmação de que o homem seria o melhor ente que a natureza teria a oferecer ao cosmos. Ora, sendo o homem sabidamente imperfeito, frágil, mortal e, no mais das vezes, vicioso e mau, a existência de um ente que lhe seja superior constitui um imperativo da razão. ${ }^{56}$ Este argumento é particularmente importante, dado que Santo Tomás de Aquino e Santo Anselmo parecem ter se baseado nele para provar a existência do Deus cristão, aduzindo que uma noção perfeita como a de Deus não poderia existir apenas como conceito na mente de seres imperfeitos, sendo forçosa, portanto, a existência ontológica e não apenas epistemológica de Deus. Para os estoicos, deus é aquele ser em relação ao qual nada maior pode ser concebido. ${ }^{57}$ Diógenes Laércio caracteriza o deus estoico como um ser vivo, imortal, racional, perfeito, pensante e dono de uma felicidade plena, incapaz de sofrer a ação de qualquer coisa má. Não possuindo forma humana, ele é o demiurgo e o pai de todas as coisas, pelas quais vela continuamente. Como são muitos os seus poderes, vários também são os seus nomes. ${ }^{58}$

A concepção dos estoicos acerca da divindade é bastante complexa, ${ }^{59}$ revelando-se ao mesmo tempo monoteísta - deus é um ser único -, politeísta ele se manifesta de várias formas de acordo com os seus poderes - e panteísta - estando em todas as partes e se expressando por meio da natureza. Segundo Duhot, ao contrário dos neoplatônicos que fundaram sua teologia negativa na transcendência absoluta de Deus, não ousando definir o que ele é, mas apenas o que ele não é, os estoicos deram origem a uma hiperteologia na qual deus é tudo. Por isso o deus estoico transcende os quadrantes limitados da nossa lógica de oposições. Ele liga a Física à Teologia e se exprime mediante todos os

55 O tema é explorado com detalhes em BOYANCÉ, 1962, p. 46-71.

56 ALGRA, 2006, p. 180-181.

57 CICÉRON, De la nature des dieux, II, VI-VII, 18 (ST, p. 415-416). Algra discorda de nossa interpretação e sustenta que, apesar da fórmula de Santo Anselmo estar presente de maneira embrionária em alguns textos estoicos semelhantes ao de Cícero que ora citamos, esses filósofos não conceberam a divindade como verdade imediata e evidente, como faz Anselmo ao derivar os atributos divinos do próprio conceito de Deus. Cf. ALGRA, 2006, p. 184.

58 DIOGĖNE LAËRCE, Vies et opinions des philosophes, VII, 147 (ST, p. 63).

59 ALGRA, 2006, p. 184-189. 
registros possíveis, sendo ao mesmo tempo transcendente e imanente, interior e exterior, pessoa e força etc. ${ }^{60}$ Não obstante, nos chocamos ao ler no artigo de Algra ${ }^{61}$ que se o deus estoico corresponde ao universo, ele necessariamente deve ser finito ${ }^{62}$ e material, características que pareciam não trazer qualquer desconforto para a Teologia do Pórtico. Na esteira do pensamento grego tradicional, os estoicos concebiam deus como o ordenador do mundo. A matéria, eterna e incriada, lhe seria anterior. A tarefa divina consistiria então em conferir forma e qualidade ao ser bruto, ao substrato material que, informado pela ação divina, se revela como universo. ${ }^{63}$ A matéria por si mesma é sem movimento e sem forma e depende de deus para se mover e se formar. ${ }^{64} \mathrm{E}$ deus quem a qualifica, apresentando-se como razão na matéria. Dessa forma, a substância é a matéria, o princípio passivo, e a causa é deus, o princípio ativo. Long aduz que o deus dos estoicos equivale à qualificação da substância. Esta, por seu turno, se determina somente graças à constante interação causal com deus. ${ }^{65}$ Tal esquema de pensamento nos recorda a distinção de Spinoza entre natura naturans e natura naturata, aquela indicando a natureza como causa ativa, ou seja, deus identificado a uma causa livre, e aquela evocando o aspecto passivo da realidade, que qualquer que seja ele, se dá por necessidade da natureza de Deus ${ }^{66}$ e é como seu espelho. De maneira semelhante ao Deus impessoal de Spinoza, o demiurgo da Stoá é extensão e pensamento ao mesmo tempo, que mais não são do que modos diversos de se conceber a substância ${ }^{67}$ presente em todas as coisas particulares, que derivam seus modos de existência dos atributos divinos. Cada coisa determinada é, para os estoicos e para Spinoza, uma ideia em Deus da qual Deus é causa. ${ }^{68}$ Segundo o estoicismo e o spinozismo, a ordem e a conexão das ideias é idêntica à ordem e à conexão das coisas no mundo ${ }^{69}$ daí por que o pensar e o agir são, para Deus, uma única coisa. ${ }^{70}$

Assim como o aristotelismo, o estoicismo é radicalmente empirista, acreditando que a existência (einai) se compõe apenas de $\operatorname{corpos}^{71}$ que

60 DUHOT, 2006, p. 79-80.

61 ALGRA, 2006, p. 185.

62 Notar a contradição dessa ideia com a informação veiculada por Diógenes Laércio, para quem o deus estoico é imortal. Cf. DIOGĖNE LAËRCE, Vies et opinions des philosophes, VII, 147 (ST, p. 63).

63 DUHOT, 2006, p. 59.

64 SEXTUS EMPIRICUS, Against the professors, 9, 75-76 (LS, p. 269).

65 LONG, 2006, p. 410.

66 SPINOZA, Ethica, I, prop. 29, esc.

67 SPINOZA, Ethica, II, prop. 7, esc.

68 SPINOZA, Ethica, II, prop. 13, esc.

69 SPINOZA, Ethica, II, prop. 7, esc.

70 LONG, 2006, p. 411-412.

71 Para o estoicismo, "corpo" é tudo aquilo que pode ser sujeito ativo ou passivo de algum fenômeno causal. 
interagem das mais diversas maneiras. Tudo que existe é corpo: eis a afirmação básica do materialismo estoico. ${ }^{72}$ Contudo, não devemos confundir tal postura com o materialismo amorfo que caracterizou a filosofia natural dos séculos XVII e XVIII. Esta, segundo White, via o mundo como uma espécie de composto formado por partículas sólidas e maçudas, regidas pela mecânica causalista. Newton ensina no seu Principia mathematica que Deus criou a matéria com partículas compactas, duras, impenetráveis e móveis chamadas globuli, para que assim a natureza tivesse duração constante. ${ }^{73}$ Ao contrário, para os estoicos o cosmos não é corpuscular e nem atomístico, assemelhandose antes a um grande corpo sem interrupções ou emendas. De acordo com a Stoá, todo o universo material está vivo e pulsa como um animal, daí porque White prefere falar em vitalismo e não em materialismo. ${ }^{74}$ No mesmo sentido, Brunschwig contrapõe a postura teleológico-vitalista dos estoicos à visão antiteleológico-mecanicista própria dos epicuristas. ${ }^{75}$ De fato, os estoicos não se confundem com os "filhos da Terra" criticados por Platão no Sofista (246a-b) e que só acreditam na realidade do que pode ser tocado e oferece resistência. ${ }^{76}$ Concordamos com Duhot quando ele reprova estudiosos que utilizam conceitos contemporâneos e classificam o estoicismo como um simples materialismo que dissolve deus em interpretações físicas racionalistas. ${ }^{77} \mathrm{Na}$ verdade, o materialismo estoico foi uma reação contra o idealismo extremado de Platão, que conferindo primazia à Ideia e às formas puras, rebaixou a matéria a um status ontológico inferior. Se, como quer Platão, entendermos que a matéria é indigna de integrar o corpo de deus, somente poderemos chegar a duas conclusões, ambas inaceitáveis para o finalismo otimista do Pórtico que vê no cosmos um sistema unívoco, contínuo, belo e racional: ou o mundo é uma criação imperfeita de deuses intermediários e subalternos, como afirmarão os neoplatônicos, ou constituiu o resultado do trabalho de um deus malévolo, raciocínio coerente desenvolvido pelos gnósticos.

Ao assumir que tudo é corpo, a Stoá não limita a esfera de seu conhecimento. Ao contrário: para nela inserir elementos intangíveis como a alma e as virtudes, os estoicos acabam por corporalizar quase todo o universo, pois para eles corpo é tudo aquilo que pode agir ou sofrer ação e não 
simplesmente o que é palpável. ${ }^{78}$ Ademais, como nos recorda Duhot, a Física do Pórtico não conhecia o princípio da inércia, segundo o qual um corpo tende a manter o seu estado de movimento ou de imobilidade. Com tal postulado em mente, físicos modernos como Newton puderam conceber o universo à semelhança de um grande relógio que, uma vez posto a funcionar por Deus mediante um "peteleco" inicial, mantém-se indefinidamente em movimento. Por seu turno, os gregos em geral e os estoicos em especial somente poderiam imaginar um universo ativo pressupondo também a existência de um ser que constantemente o ordena e vigia. Este ente é o deus da Stoá, que para agir no cosmos precisa ser um corpo. Toda ação física a distância é tida como impossível para o Pórtico, razão pela qual seu deus é corpóreo e está em todos os cantos do universo, tocando-o na integralidade de sua superfície, imanente e necessário a todos os fenômenos físicos. Desse modo, a Física estoica parece ser causalista, inadmitindo a existência de movimentos sem causa no universo. Se houvesse algo no cosmos como uma causa incausada, todo o edifício racional da realidade desabaria. Todavia, lembremo-nos da advertência de Aubenque, para quem o termo "causalismo" se revela impróprio para descrever a mecânica cósmica do Pórtico. Acreditar na ação de determinadas causas produtoras de certos efeitos implica conceber séries causais autônomas e limitadas. Contudo, para a Stoá tudo está ligado: não há séries causais separadas, mas antes um tipo de simpatia universal, uma teia que unifica todos os eventos do mundo de maneira harmônica e racional, coordenando o movimento do todo e a coesão da substância. ${ }^{79}$ Tal concepção afasta radicalmente o Pórtico das ideias próprias do epicurismo, escola que não admite nenhum finalismo cósmico e nem reconhece qualquer racionalidade na Providência. ${ }^{80}$

Baseando-se em certas ideias de Heráclito, os estoicos descrevem os dois princípios (archai) - básicos, incorpóreos, informes e indestrutíveis - que regem o universo corpóreo: o primeiro, passivo (to paschon), radica-se na matéria, e o segundo, ativo (to poioun), identifica-se com a força racional que age sobre essa mesma matéria. ${ }^{81}$ Segundo Hahm, o estoicismo redistribuiu as quatro causas de Aristóteles em dois blocos, de maneira que o princípio ativo congregaria a causa motriz, a causa formal e a causa final, enquanto o princípio passivo corresponderia à causa material. ${ }^{82} \mathrm{O}$ princípio passivo é

78 BRUNSCHWIG, 2006, p. 234-235.

79 MARCO AURÉLIO, Meditações, VI, 35, p. 297.

80 BERA, 2002, p. 19.

81 SÉNECA, 2006, p. 167.

82 HAHM, 1977, p. 44. 
amorfo e não possui poder de coesão ou de movimento. Já o princípio ativo é chamado de deus, de destino ou simplesmente de $\log o s .{ }^{83}$ Ele é eterno e se move por si próprio, sendo responsável por toda forma, qualidade, individuação, diferenciação, coesão e mudança no mundo. Para Crisipo, o princípio ativo se compõe de elementos leves e sutis, como o são o fogo - também chamado de ether ${ }^{84}$ - e o ar, enquanto o princípio passivo é feito de elementos mais rudes: terra e água. Ambos existem em todas as coisas do universo e agem de modo conjunto, apesar de estarem separados e de conservarem suas características e qualidades específicas. ${ }^{85} \mathrm{~A}$ existência se mantém por força da mistura harmoniosa dos quatro elementos, dentre os quais o fogo - chamado de artesão por Zenão - representa um papel preponderante. ${ }^{86}$ Durante as conflagrações, a terra, a água e o ar são reabsorvidos pelo fogo, razão seminal do mundo. $\mathrm{Na}$ realidade, esses três elementos não são seres diversos do fogo; são o próprio fogo, que se apresenta de diversos modos devido às diferentes tensões internas que o informam. Pode-se dizer então, com Bréhier, que todos os corpos são momentos ou aspectos da existência de um único ser, o fogo, cuja história corresponde à história do mundo. ${ }^{87}$

O universo existe graças a uma espécie de harmonia que garante o acordo de todas as coisas terrestres e celestes. ${ }^{88}$ É que, segundo os estoicos, existem três tipos básicos de mistura: a) a justaposição, em que partes de elementos diferentes são mescladas, mas não dão origem a um terceiro elemento, como na mistura de sal e açúcar; b) a fusão, em que se cria um novo ente com base na mistura de outros; c) a mescla total (krasis di'holón, total simul), na qual a mistura destrói os elementos originais mantendo, contudo, as suas propriedades específicas. Nesta terceira espécie de mistura os elementos originais podem ser sintetizados novamente e extraídos da mescla. De acordo com a Física estoica, é este tipo de mistura que compõe o universo, o que explica a necessidade das periódicas conflagrações em que os elementos originais - fogo, água, ar e terra - são separados da mescla para se associarem novamente em um novo ciclo. ${ }^{89} \mathrm{Com}$ base em Alexandre de Afrodísias, White explica que por conta da mistura universal deus permeia toda a matéria, formando-a e conformando-a, ${ }^{90}$ da mesma maneira que a alma faz com o

83 DIOGÈNE LAËRCE, Vies et opinions des philosophes, VII, 134 (ST, p. 58-59).

84 DIOGÈNE LAËRCE, Vies et opinions des philosophes, VII, 137 (ST, p. 59).

85 BOBZIEN, 2005, p. 17.

86 DIOGĖNE LAËRCE, Vies et opinions des philosophes, VII, 137 (ST, p. 59).

87 BRÉHIER, 1997, p. 10-11.

88 DIOGĖNE LAËRCE, Vies et opinions des philosophes, VII, 140 (ST, p. 61).

89 ALEXANDER, On mixture, 216, 14 e 218, 6 (LS, p. 290-291) e STOBAEUS, Anthologium, I, 155 (LS, p. 291 ).

90 WHITE, 2006, p. 148. 
corpo, estando em todos os seus lugares ao mesmo tempo. ${ }^{91}$ Há contato por toda a parte e não simplesmente uma série de elementos causais que fazem girar o cosmos. No universo estoico tudo está ligado a tudo. Não importa o tamanho da área tridimensional ocupada pela mescla total, uma vez que ela se espalha por todo o universo. Chegamos assim a entender que ela não é constituída por corpúsculos ou pedaços que se unem, mas por um único grande corpo no qual inexistem junções ou superfícies separadas. ${ }^{92} \mathrm{Com}$ o estoicismo inaugura-se o anticorpuscularismo, teoria segundo a qual todos os corpos apresentam estrutura radicalmente contínua, o que parece a White bem pouco promissor para o desenvolvimento da Física contemporânea..$^{93}$ Ele está errado. Antecipando algumas teses da Física Quântica com a ideia de mescla total, os filósofos do Pórtico puderam afirmar a interpenetrabilidade dos corpos, eis que não há espaços vazios no mundo. Todos os corpos estão misturados em todos os seus pontos, não havendo conteúdo e nem continente: tudo está em tudo. ${ }^{94}$

Os estoicos oferecem uma visão global e unitária do mundo pretendendo nos convencer de que há um governo racional da realidade. ${ }^{95} \mathrm{O}$ universo se apresenta como corpo unificado que se diversifica pela ação das várias tensões internas que determinam o lugar de cada corpo aparentemente particular na tessitura do cosmos. ${ }^{96}$ Segundo a Stoá, há apenas um lugar absoluto no mundo, ocupado pela sua alma, o único corpo verdadeiro. A alma do mundo penetra os corpos parciais e é penetrada por cada um deles em lugares específicos, o que cria a ilusão da pluralidade de corpos. ${ }^{97}$ Os limites (pérata) entre os corpos subsistem apenas na mente enquanto "ficções de geômetras" 98 e, como tal, são meros construtos intelectuais ${ }^{99}$ e não propriamente incorpóreos, como os classifica Plutarco em prejuízo do Pórtico. ${ }^{100}$ Se os limites fossem incorpóreos, um corpo iria tocar outro com e em algo imaterial. Assistiríamos assim à ação de um incorpóreo, o que é impossível, por ser este ente totalmente passivo. Em uma tal hipótese, a Física estoica seria destruída.

91 DIOGĖNE LAËRCE, Vies et opinions des philosophes, VII, 138 (ST, p. 60).

92 WHITE, 2006, p. 164.

93 WHITE, 2006, p. 166.

94 BRÉHIER, 1997, p. 41.

95 FREDE, 2006, p. 204-205.

96 BRÉHIER, 1997, p. 42.

97 BRÉHIER, 1997, p. 53.

98 WHITE, 2006, p. 166.

99 A leitura dos textos de DIOGĖNE LAËRCE, Vies et opinions des philosophes, VII, 135 (ST, p. 59) e de PROCLUS, On Euclid's elements, I, 89 (LS, p. 299) parece legitimar essa interpretação, que é endossada por Long e Sedley, LS, p. 301 e WHITE, 2006, p. 167.

100 PLUTARCH, On common conceptions, 1080e (LS, p. 299). 
A Cosmologia estoica não admite o atomismo dos epicureus, inscrevendose entre as teorias filosóficas antigas que descreviam a realidade como um continuum $^{101}$ indeterminado - mas determinável - de espaço. ${ }^{102}$ Uma das grandes intuições do Pórtico, que novamente pressagiou as atuais concepções da Física Quântica, reside na crença de que os corpos são divisíveis ao infinito, não havendo que se falar em unidades básicas da existência. Para os estoicos, qualquer parcela de um corpo pode ser fracionada indefinidamente, o que garante a linearidade e a unicidade de seu sistema cosmológico. O lógos se manifesta em cada uma das partes e, ao mesmo tempo, em todo o universo, penetrando o Real de modo inteligível e progressivo: nos ossos o lógos se mostra como força de coesão; nas plantas, como princípio de crescimento; na parte diretora da alma, revela-se enquanto intelecto ${ }^{103}$ que irmana homens e deuses. Trata-se de uma scala naturae pela qual a razão está em todos os corpos, do mais bruto ao mais sutil. ${ }^{104}$ Perpassando toda a realidade, o lógos estoico inaugura um materialismo sui generis, integralmente racional, unificado e fundamentado em uma causalidade inescapável própria de um continuum energético de corpos.

Para comprovar a tese estoica acerca da comunicação entre todos os elementos do mundo, Crisipo oferece uma resposta paradoxal ao problema do continuum espacial posto por Demócrito, que nos convida a considerarmos um cone e as suas várias seções cônicas, circulares e vizinhas. Se afirmarmos que tais seções são desiguais umas das outras, de maneira que há seções menores e maiores de acordo com o aumento da abertura circular do cone, devemos forçosamente admitir que a superfície (epiphaneía) do cone é irregular e não lisa, pois as diferenças entre os tamanhos das seções, ainda que mínimas, produziriam rugosidades, o que não corresponde à realidade fenomênica. Por outro lado, se entendermos que as seções são iguais, não se trata, obviamente, de um cone, mas de um cilindro. Pois bem, Crisipo resolve o paradoxo afirmando que as seções cônicas não são iguais e nem desiguais entre si: ${ }^{105}$ elas simplesmente não existem, assim como não existe qualquer divisão no espaço. ${ }^{106}$ Todos os corpos são, em última análise, um único e imenso corpo: o

101 DIOGÈNE LAËRCE, Vies et opinions des philosophes, VII, 150 (ST, p. 64), SEXTUS EMPIRICUS, Against the professors, 10, 121-126 e 139-142 (LS, p. 299-300) e STOBAEUS, Anthologium, I, 142 (LS, p. 297).

102 BOBZIEN, 2005, p. 16-17.

103 DIOGĖNE LAËRCE, Vies et opinions des philosophes, VII, 156 (ST, p. 60).

104 FREDE, 2006, p. 206.

105 PLUTARQUE, Des notions communes contre les stoïciens, XXXIX (ST, p. 171).

106 BRÉHIER, 1997, p. 7-8. 
universo. Nele tudo está interligado e somente por meio de operações mentais arbitrárias falamos em partes e em todo.

Tudo está conectado porque tudo é um único corpo. Acreditar que os corpos terminam onde percebemos as suas superfícies não passa de um erro grosseiro, uma ilusão proporcionada pelos nossos sentidos imperfeitos. De acordo com a Stoá, os corpos não se tocam por meio de suas superfícies; eles se interpenetram. O que experimentamos sensivelmente como a aparente superfície de determinado corpo nada mais é do que o começo de sua degradação progressiva, que termina apenas nos limites exteriores do universo (to hólon) que fazem fronteira com o vazio. ${ }^{107}$ Por meio da mescla total, a racionalidade cósmica estoica une sem confundir, encontrando a unidade na diversidade fenomênica. Por isso estamos sujeitos a uma única lei natural (nómos physikós), poderosa o suficiente para sujeitar o mundo a ciclos periódicos nos quais tudo se dissolve pela ação das conflagrações (ekpyrôsis). Mas o cosmos é eterno. Deus não o destrói, apenas o consome por meio das conflagrações de modo a recriá-lo infinitamente a partir da unidade primeva. ${ }^{108}$ A teoria das conflagrações foi gestada pelo antigo estoicismo para fazer face ao criticismo dos peripatéticos. Baseados nos argumentos de Aristóteles ( $D e$ caelo $279 \mathrm{~b}$ et seq.), eles acreditavam na eternidade do mundo. ${ }^{109}$ Também os Acadêmicos, avessos aos dogmatismos estoicos, negavam o eterno retorno que fundamenta as conflagrações periódicas. Dentro da própria Stoá surgiram dissensões. Boetus, discípulo de Diógenes de Babilônia, se perguntava como o ser pode surgir do não-ser, pois segundo a ideia tradicional o mundo seria totalmente destruído para depois renascer do nada. E mais: de que se ocupa deus durante as conflagrações? Quais seriam as causas desse cataclismo, já que nada externo ou interno ao universo pode extingui-lo? ${ }^{110}$ A reação ortodoxa não tardou. Explica o Pórtico que o motivo das conflagrações reside na gradativa falta de umidade no mundo, fenômeno que seca o cosmos e provoca periodicamente um incêndio purificador. Segundo o testemunho de Crisipo, o mundo arde quando não resta mais água sobre a terra, o que ocorre a cada 365 vezes 18.000 anos. ${ }^{111}$ 
Provavelmente os estoicos tinham em mente o grande ano (annus magnus ou perfectus) $)^{112}$ - aludido por Platão (Timeu, 39d) e por Cícero ${ }^{113}$ - quando imaginaram as conflagrações. Grande ano é o período que os corpos celestes levam para se encontrar todos na mesma posição relativa, i.e., uns em relação aos outros. Parece que o conceito foi introduzido por Pitágoras, ${ }^{114}$ tendo sido de capital importância para os alquimistas, que nele viam sentidos herméticopropiciatórios. A postulação do grande ano também foi fundamental para a astronomia indiana, que o conheceu graças a fontes gregas hoje perdidas. ${ }^{115}$ Os medievais calcularam-no em 15.000 anos solares, enquanto modernamente diz-se que equivale a 25.868 anos solares, ${ }^{116}$ tempo que o ponto da Primavera leva para percorrer todo o Zodíaco. ${ }^{117}$ Assim, as conflagrações ocorreriam a cada grande ano, ${ }^{118}$ quando a Terra, as estrelas e os demais corpos celestes estivessem posicionados exatamente como estavam no momento da criação do cosmos. Na tessitura teórica do estoicismo as conflagrações garantem a preeminência do princípio da mudança na continuidade, garantidor da incorruptibilidade do fogo-demiurgo original que, diferentemente do fogo comum integrante dos quatro elementos, ${ }^{119}$ identifica-se com Zeus, ${ }^{120}$ o pai de todas as coisas e senhor do tempo. ${ }^{121}$ A teoria das conflagrações demonstra a constância da Providência condutora do mundo, valendo como garantia contra as mudanças e a aparente instabilidade das coisas: o destino de tudo é conflagrar-se, queimar-se no fogo-artesão descrito por Heráclito e renascer para cumprir periódicos ciclos cósmicos.

Segundo Sêneca, após o mundo ter se dissolvido e os deuses terem se mesclado em um só com a suspensão momentânea das leis da natureza, Júpiter, confiando em si, recolhe-se à sua interioridade para meditar e dar origem novamente ao mundo, postura que deve ser imitada pelo sábio estoico quando se encontra em situações tidas pelos homens comuns como negativas. Espelhando-se no Júpiter das conflagrações, o sábio deve se concentrar em si, ficar sozinho consigo mesmo ${ }^{122}$ e criar um novo universo ético. Com base em

112 WHITE, 2006, p. 157.

113 CICÉRON, De la nature des dieux, II, XX, 51-53 (ST, p. 427-428).

114 ARNOLD, 1971, p. 193.

115 JONES, 2006, p. 373.

116 Para o cálculo do grande ano, cf. WAERDEN, 1952, p. 129-157.

117 ROOB, 2006, p. 72.

118 SVF, II, 596, 599 e 625.

119 STOBAEUS, Anthologium, I, 213 (LS, p. 275).

120 Também chamado pelos estoicos de deus, inteligência ou destino. Cf. DIOGÈNE LAËRCE, Vies et opinions des philosophes, VII, 135 (ST, p. 59).

121 AETIUS, De placitis reliquiae, I, 7, 33 (LS, p. 274).

122 SÉNECA, 2006, p. 38-39. 
evidências doxográficas da autoria de Orígenes e de Plutarco, White nos diz que o deus estoico existe em sua plenitude apenas durante as conflagrações, quando o todo se recolhe ao todo e o bem-razão se concentra. Durante a conflagração deus detém o todo da substância (tèn hólen ousían), sendo que nesse momento a alma do mundo cresce continuamente até consumir toda a matéria, interiorizando-a. ${ }^{123}$ Diferentemente, nos períodos "normais" da existência do mundo, deus se apresenta apenas enquanto imanência, identificando-se com o princípio ativo ou alma universal, o que levou muitos filósofos antigos a criticarem o estoicismo por confundir, na pessoa de deus, os conceitos de matéria e forma. Os estoicos responderam dizendo que as qualidades das coisas corpóreas são, elas mesmas, corpos, ${ }^{124}$ com o que a imanência formal de deus passa a ser entendida como elemento material.

Durante a conflagração tudo se reverte ao princípio ativo, tudo se transforma em fogo e em espírito (pneûma). Panécio dissente da ortodoxia estoica em razão desse ponto específico. Para ele não há conflagrações, eis que o mundo seria eterno. Isso também indicaria que, ao contrário do que pensavam Zenão e Crisipo, o mundo não é um ser vivo, já que nenhum animal pode viver para sempre. ${ }^{125}$ Profundamente materialista, Panécio julga impossível que o mundo se reverta ao princípio ativo, assim como é impensável que a alma sobreviva sem o corpo. Na verdade, diz Panécio, a mistura entre os quatro elementos configura-se como uma proporção constante e eterna. ${ }^{126}$ Contudo, a ideia de proporção ou medida perpétua que guia e mantém unívoco o universo não parece ser conflitante com a possibilidade das conflagrações; ao contrário, estas pressupõem aquela. A tese de Panécio não resiste à argumentação de Heráclito, inspiração maior do Pórtico: "Esta ordem do mundo [a mesma de todos] não criou nenhum dos deuses, nem dos homens, mas sempre existiu e existe e há-de existir: um fogo sempre vivo, que se acende com medida e com medida se extingue". ${ }^{127}$

A Física do estoicismo não se resolve em qualquer evolucionismo, dado que o mundo e os homens são sempre os mesmos nos infinitos ciclos cósmicos que atravessam. No ritmo vital de Zeus assentam-se as noções de estabilidade e de mudança, visto que os ciclos são necessários e não lúdicos ou gratuitos. O fogo original se entremostra absoluto, fatal e imodificável, tal como a fortaleza moral no homem de virtude, que não se incomoda 
com aquilo que lhe é exterior. ${ }^{128} \mathrm{O}$ mundo se dilata no vazio infinito e arde graças à ação do fogo-demiurgo, que é o próprio Zeus. Garante-se assim a vitalidade cósmica e o dinamismo do lógos, que submete o universo à lei do eterno retorno, tudo regenerando e divinizando. Na contramão de Platão e de Aristóteles e retomando o pensamento pré-socrático, os estoicos entendiam que o mundo deve ser corruptível, já que é produto de geração. Segundo a imutável lei da natureza, tudo o que nasce deve morrer, inclusive o mundo. Todavia, ele renasce continuamente pela ação da palingenesia. ${ }^{129}$ Depois da conflagração, o universo se refaz e se apresenta exatamente como era antes, inclusive com as mesmas pessoas, que repetirão os mesmos atos e viverão as mesmas vidas. ${ }^{130}$ Haverá de novo um Sócrates e um Platão, comenta o bispo e filósofo neoplatônico Nemésio com fincas em textos estoicos hoje perdidos.

Não podemos então falar em novos ciclos, mas antes na infinita recorrência ${ }^{131}$ de um mesmo ciclo ${ }^{132}$ que se repete indefinidamente. ${ }^{133}$ Tal ocorre assim porque o mundo, governado pela razão, se organiza da melhor maneira possível, o que corresponde a apenas uma possibilidade entre infinitas outras. Isso quer dizer que, para o Pórtico, o mundo como é corresponde exatamente ao mundo como deve ser segundo a lei cósmica, motivo pelo qual nada pode ser renovado com as conflagrações, que criam sempre o mesmo mundo porque ele é o melhor dentre todos os possíveis. ${ }^{134} \mathrm{O}$ mundo compõe-se assim de uma substância única que mantém as coisas em constante movimento, umas cedendo lugar às outras periodicamente segundo a lei do eterno retorno ${ }^{135}$ na qual Borges viu a marca indelével do pensamento hindu, presente tanto na filosofia pitagórica como na estoica. Segundo os antigos Vedas, o mundo morre e renasce infinitamente, repetindo grandes ciclos que se contam por calpas, unidade de medida que transcende a imaginação humana. ${ }^{136}$

Conclui-se assim que para os estoicos, à diferença dos epicuristas, a Física não se identifica com um simples processo de explicação e de desmistificação da realidade natural, correspondendo antes a uma moral e a um modo de vida

128 ILDEFONSE, 2007, p. 64-66.

129 REALE, 2004, p. 116-117.

130 LACTANTIUS, Divine institutes, 7, 23 (LS, p. 308) e ORIGEN, Against Celsus, 4, 68 e 5, 20 (LS, p. 310).

131 Para o entendimento do conceito estoico de recorrência, cf. SALLES, 2003, p. 253-272.

132 EUSEBIUS, Evangelical preparation, 15, 19 (LS, p. 309).

133 ALEXANDER, On Aristotle's prior analytics, 180, $33-36$ e 181, $23-31$ (LS, p. 309-310) e SIMPLICIUS, On Aristotle's physics, 886, 12-16 (LS, p. 309).

134 ARISTOCLES apud EUSEBIUS, Evangelical preparation 15, 14, 2 (LS, p. 276).

135 ÉPICTÈTE, Entretiens, III, XXIV, 10 (ST, p. 1021).

136 "Imaginemos una pared de hierro. Tiene dieciséis millas de alto y cada seiscientos años un ángel la roza. La roza con una tela finísima de Benares. Cuando la tela haya gastado la muralla que tiene dieciséis millas de alto, habrá pasado el primer día de una de las calpas y los dioses duran lo que duran las calpas y despúes mueren" (BORGES, 2005, p. 272-273). 
racional. A Física estoica já é sabedoria e não apenas um simples meio para alcançá-la.

\section{Referências}

ALGRA, Keimpe. Teologia estóica. In: INWOOD, Brad (Org.). Os estóicos. Trad. Paulo Fernando Tadeu Ferreira e Raul Fiker. São Paulo: Odysseus, 2006. p. 171-198. ARNIM, Johannes von (Org.). Stoicorum veterum fragmenta. Stuttgart: Teubner, 1968. $4 \mathrm{v}$.

ARNOLD, Edward Vernon. Roman stoicism: being lectures on the history of the stoic philosophy with special reference to its development within the roman empire. Freeport: Books for Libraries, 1971.

ARTHUR, E. P. The stoic analysis of the mind's reactions to presentations. Hermes: Zeitschrift fur Klassische Philologie, Wiesbaden, n. 111, p. 69-78, 1983.

BERA, Eduardo Gil (Org.). Pensamiento estoico. Vários trads. Sel. y introd. Eduardo Gil Bera. Barcelona: Edhasa, 2002.

BLOCH, Ernst. Derecho natural y dignidad humana. Trad. Felipe González Vicén. Madrid: Aguilar, 1980.

BOBZIEN, Sussane. Determinism and freedom in stoic philosophy. Oxford: Oxford University, 2005.

BORGES, Jorge Luis. El budismo. In: Obras completas. 2. ed. Buenos Aires: Emecé, 2005. v. 3.

BOYANCÉ, Pierre. Les preuves stoiciennes de l'existence des dieux d'après Cicéron. Hermes: Zeitschrift fur Klassische Philologie, Wiesbaden, n. 90, p. 46-71, 1962.

BRÉHIER, Émile. La théorie des incorporels dans l'ancien stoïcisme. 9. ed. Paris: J. Vrin, 1997.

BRUNSCHWIG, Jacques. Metafísica estóica. In: INWOOD, Brad (Org.). Os estóicos. Trad. Paulo Fernando Tadeu Ferreira e Raul Fiker. São Paulo: Odysseus, 2006. p. 229257.

CASTON, Victor. Something and nothing: the stoics on concepts and universals. Oxford Studies in Ancient Philosophy, Oxford, n. 17, p. 215-247, 1999.

CHÂTELET, François (Org.). História da filosofia, idéias e doutrinas. Trad. Maria José de Almeida. Rio de Janeiro: Zahar, 1972. v. 1.

DUHOT, Jean-Joël. Epicteto e a sabedoria estóica. Trad. Marcelo Perine. São Paulo: Loyola, 2006.

FREDE, Dorothea. Determinismo estóico. In: INWOOD, Brad (Org.). Os estóicos. Trad. Paulo Fernando Tadeu Ferreira e Raul Fiker. São Paulo: Odysseus, 2006. p. 199-227.

GOLDSCHMIDT, Victor. Le système stö̈cien et l'idée de temps. Paris: J. Vrin, 1953. HAHM, David E. The origins of stoic cosmology. Columbus: Ohio State University, 1977. 
HANKINSON, R. James. Estoicismo e medicina. In: INWOOD, Brad (Org.). Os estóicos. Trad. Paulo Fernando Tadeu Ferreira e Raul Fiker. São Paulo: Odysseus, 2006. p. 327-342.

ILDEFONSE, Frédérique. Os estóicos I: Zenão, Cleantes, Crisipo. Trad. Mauro Pinheiro. Rev. técnica de Tadeu Mazzola Verza. São Paulo: Estação Liberdade, 2007. INWOOD, Brad; GERSON, Lloyd P. (Org.). Hellenistic philosophy: introductory readings. Trad., introduction and notes Brad Inwood and Lloyd P. Gerson. 2. ed. Indianápolis; Cambridge: Hackett, 1997.

IRWIN, Terence Henry. Naturalismo estóico e seus críticos. In: INWOOD, Brad (Org.). Os estóicos. Trad. Paulo Fernando Tadeu Ferreira e Raul Fiker. São Paulo: Odysseus, 2006. p. 381-401.

JACKSON-McCABE, Matt. The stoic theory of implanted preconceptions. Phronesis: A Journal for Ancient Philosophy, Leiden, n. 49, p. 323-347, 2004.

JONES, Alexander. Os estóicos e as ciências astronômicas. In: INWOOD, Brad (Org.). Os estóicos. Trad. Paulo Fernando Tadeu Ferreira e Raul Fiker. São Paulo: Odysseus, 2006. p. 363-380.

KIRK, Geoffrey S.; RAVEN, John Earle; SCHOFIELD, Malcolm. Os filósofos pré-socráticos: história crítica com selecção de textos. Trad. Carlos Alberto Louro Fonseca. 5. ed. Lisboa: Calouste Gulbenkian, 2005.

LIMA VAZ, Henrique Cláudio de. Escritos de filosofia IV: introdução à ética filosófica 1. São Paulo: Loyola, 1999.

LONG, Anthony A. Estoicismo na tradição filosófica: Spinoza, Lipsius, Butler. In: INWOOD, Brad (Org.). Os estóicos. Trad. Paulo Fernando Tadeu Ferreira e Raul Fiker. São Paulo: Odysseus, 2006. p. 403-433.

LONG, Anthony A.; SEDLEY, David N. (Org.). The hellenistic philosophers. Cambridge: Cambridge University, 2006. (Translations of the principal sources, with philosophical commentary, v. 1).

MARCO AURÉLIO. Meditações. Trad. Jaime Bruna. In: Os pensadores. São Paulo: Abril Cultural, 1973. v. 5.

REALE, Giovanni. La filosofia di Seneca come terapia dei mali dell'anima. 5. ed. Milano: Bompiani, 2004.

ROOB, Alexander. O museu hermético: alquimia \& misticismo. [S.1.] (Portugal): Taschen, 2006.

SALLES, Ricardo. Determinism and recurrence in early stoic thought. Oxford Studies in Ancient Philosophy, Oxford, n. 24, p. 253-272, 2003.

SCHUHL, Pierre-Maxime (Ed.); CLÉANTHE; DIOGĖNE LAËRCE; PLUTARQUE; CICÉRON; SÉNÈQUE; ÉPICTÈTE; MARC-AURÈLE. Les stoïciens. Trad. Émile Bréhier. Bibliothèque de la Pléiade. Paris: Gallimard, 2002.

SELLARS, John. Stoicism. Berkeley: University of California, 2006.

SÉNECA, Lucio Anneo. Cartas a Lucilio. Trad. Vicente López Soto. 3. ed. Barcelona: Juventud, 2006. XCV, 13-15. 
SÊNECA. Sobre a vida feliz. Trad., introdução e notas João Teodoro D’Olim Marote. São Paulo: Nova Alexandria, 2005.

SPINOZA, Ethica, I, prop. 17, corol. 2, esc. In: SPINOZA, Baruch. The collected works of Spinoza. Ethica. Trad. and edition E. Curley. Princeton: Princeton University, 1985. v. 1.

TATAKIS, Basile N. Panétius de Rhodes, le fondateur du moyen stoicisme: sa vie et son oeuvre. Paris: J. Vrin, 1931.

VERBEKE, Gerard. L'évolution de la doctrine du pneuma: du stoicisme a S. Augustin. Paris: Desclée de Brouwer; Louvain: Institut Superieur de Philosophie, 1945.

WAERDEN, Bartel Leendert van der. Das grosse Jahr und die ewige Wiederkehr. Hermes: Zeitschrift fur Klassische Philologie. Wiesbaden, n. 80, p. 129-157, 1952.

WHITE, Michael J. Filosofia natural estóica (física e cosmologia). In: INWOOD, Brad (Org.). Os estóicos. Trad. Paulo Fernando Tadeu Ferreira e Raul Fiker. São Paulo: Odysseus, 2006. p. 139-169. 